\title{
The participation of chlorophyllase in chlorophyll metabolism
}

\author{
MARIA DRĄŻKIEWICZ, ZBIGNIEW KRUPA
}

\begin{abstract}
Department of Plant Physiology, Maria Curie-Skłodowska University, Akademicka 19, 20-033 Lublin, Poland
\end{abstract}

(Received: January 29, 1990. Accepted: September 19, 1990)

\begin{abstract}
Although the breakdown of chlorophylls can easily be visually recognized, the fate of these photosynthetic pigments as well as their catabolism is still largely unknown. In the past, the enzyme called "chlorophyllase" (chlorophyll-chlorofillido-hydrolase, EC 3.1.1.14) had been thought to participate both in the biosynthesis and in the degradation of chlorophylls. It is, however, clear at present that in vivo this enzyme is involved rather in the first steps of chlorophyll degradation.
\end{abstract}

Key words: chlorophyllase, chlorophyll metabolism

\section{INTRODUCTION}

It is estimated that on average a billion tonnes of chlorophyll are degraded each year on land and in the oceans. Although chlorophyll breakdown is the most visually obvious of all biochemical processes, the fate of this plant photosynthetic pigment is largely unknown. Its biosynthesis is recognized early as the characteristic "greening up" of plants, its degradation manifests itself as "yellowing" due to preponderance of carotenoids. In agriculture, disappearance of chlorophyll predicts ripening of crops and fruits. It may also have a role in the control of senescence and plant longevity. Autumnal disappearance of chlorophyll in leaves is a major attraction of this season of the year. It is, however, surprising how limited is our deeper knowledge of the catabolism of this class of plant pigments. Chlorophyll has been shown to be a substrate for a number of oxidative and hydrolytic activities occurring in green tissues, but 
the sequence in which these enzymes attack chlorophyll remains to be established.

Although there is still no coordinated scheme on the pathway of chlorophyll breakdown, the significantly and rapidly growing literature has forced us to restrict our considerations to only one, but the most controversial enzyme taking part in the above-mentioned phenomenon. It is chlorophyllase which has been implicated many times both in the degradation as well as in the biosynthesis of chlorophyll.

\section{CHLOROPHYLLS AND THEIR DERIVATIVES}

Since this review is not primarily devoted to detailed considerations of the origin and the chemical structure of chlorophylls, only some fundamental features and chemical properties helping understand the action of chlorophyllase on these pigments will be presented here. Chlorophylls are a family of compounds that are magnesium complexes of tetrapyrrole derivatives. In general, they are dihydroporphyrins with one of the four pyrrole rings of the porphyrin reduced (Fig. 1). In contrast, bacteriochlorophylls are based on the tetrahydroporphyrin structure, in which two pyrrole rings have been reduced (Fig. 1). Unusual exceptions are the algal chlorophylls $c 1$ and $c 2$ based on unreduced porphyrin. All chlorophyll porphyrins and their derivatives are esterified with phytol or, less commonly, the related terpenoids such as farnesol or geranyl geraniol (Holden 1976, Jackson 1976, Jones 1979, Castelfranco and Beale 1983). Chlorophyll $a$ is the most aboundant chlorophyll found in all oxygen-evolving organisms. In higher plants as well as in some algae, this chlorophyll coexists with chlorophyll $b$. They differ only in the substituent at the $\mathrm{C}-7$ carbon atom, chlorophyll $a$ having a $-\mathrm{CH}_{3}$ group and chlorophyll $b$-CHO group (Seely 1966). The ratio between chlorophyll $a$ and chlorophyll $b$ varies from 2 to 4.5 depending upon the species and

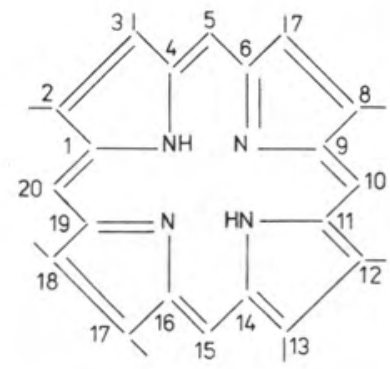

Porphyrin

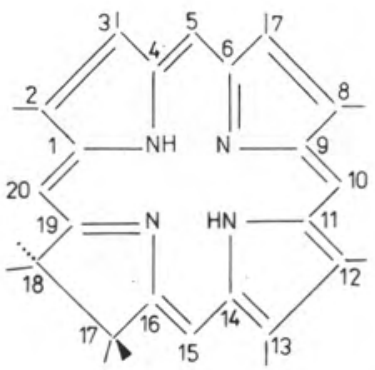

Dihydroporphyrin (chlorin)

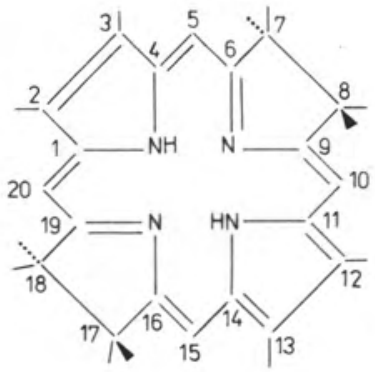

Tetrahydroporphyrin (bacteriochlorin)

Fig. 1. Structure of porphiryn precursors of major chlorophyll pigments 
irradiance (Björkmann 1981). Chlorophylls $c$ and $d$ occur in diatoms, dinoflagellates and brown algae. Chlorophyll $c$, in contrast to chlorophyll $a$, lacks the phytol moiety and its pyrrole ring is not reduced. Chlorophyll $d$ is 2-desvinyl, 2-formyl chlorophyll $a$. In cyanobacteria and red algae chlorophyll $a$ is the only chlorophyll present. Bacteriochlorophyll $a$ and $b$ are present in almost all photosynthetic bacteria. In Chlorobacteriaceae it is the minor chlorophyll. The major pigments are bacteriochlorophylls $c$ and $d$ (Jackson 1976, Jones 1978).

Chlorophylls can be readily converted, both in vivo and in vitro, to a number of characteristic derivatives with the retained macrocyclic ring. The simplest conversion is the loss of the central magnesium atom which gives the product known as pheophytin (Fig. 2). Hydrolysis of the ester bond between the macrocyclic ring and long chain alcohol results in the formation of chlorophyllide, while both above-mentioned reactions yield pheophorbide (Fig. 2, Svec 1978).

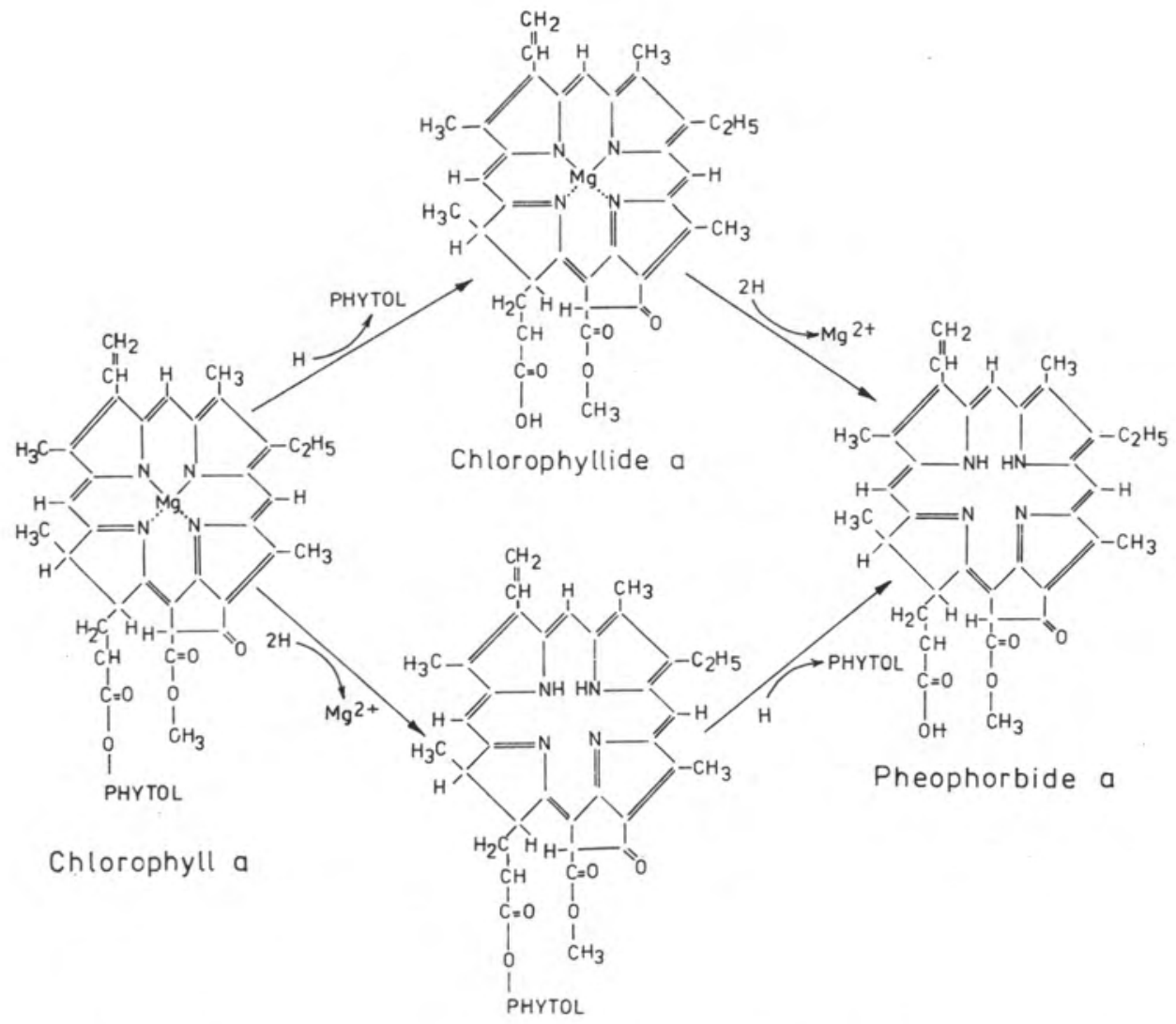

Pheophytin a

Fig. 2. Chlorophyll derivatives formed by removal of phytol side chain and/or $\mathrm{Mg}^{2}{ }^{+}$ 
All chlorophylls have characteristic UV and visible absorption spectra. They are important in identifying chlorophylls and the products of their breakdown. Chlorophylls, because of the delocalized electron system characteristic for all porphyrins, exhibit a strong Soret band at about $400 \mathrm{~nm}$. However, there is also a strong light absorbance in the region of $650 \mathrm{~nm}$ responsible for their green pigmentation. The ratio of red to blue absorbance can be used to identify the pigment (Vern on 1960, Strain et al. 1963, Jones 1969, Wintermanns 1969, Svec 1978). The centrally located magnesium atom makes little contribution to the overall chromophore as does the phytyl group that can be removed with no significant effect on the spectra (Hendry et al. 1987). Bacteriochlorophylls have different absorption spectra than chlorophylls because of the additional reduced pyrrole ring. Most characteristic is that they have no absorption band around $650 \mathrm{~nm}$, but a strong peak at about $770 \mathrm{~nm}$. The Soret band is blue-shifted towards $360 \mathrm{~nm}$. For this reason bacteriochlorophyll $a$ appears pink to our eyes.

A major problem in any investigations of the breakdown of chlorophyll is the extent to which degradation occurs biochemically (specific enzymes) or chemically without enzymic influence. In the latter case one may consider herbicidal damage or photodegradation of chlorophyll, which may occur during plant senescence. Chlorophylls possessing no polar or hydrophilic groups are soluble in lipids but almost totally insoluble in aqueous systems in the physiological $\mathrm{pH}$ range. This property can be used in the extraction and purification of chlorophylls with organic solvents, but it is also a major problem in experiments on chlorophyll breakdown. The ease with which the loss of the chelated magnesium atom may occur in diluted acids, or the loss of phytol in stronger acids or in the presence of oxidizing agents or alkali, is a potential cause of chlorophyll degradation artifacts easily produced in inadequately buffered solutions (Bacon and Holden 1967).

\section{SOME GENERAL PROPERTIES OF CHLOROPHYLLASE}

Chlorophyllase (chlorophyll-chlorofillido-hydrolase, EC 3.1.1.14), known since 1913 (Willstätter and Stoll 1913), is widely distributed in higher plants and algae (Ardao and Vennesland 1960, Shimizu and Tamaki 1963, Berret and Jeffrey 1964, Böger 1965, Ziegler and Schanderl 1969, Aiga and Sasa 1970, Bacon and Holden 1970, McFeeters et al. 1971, Terpstra 1976, 1977, 1978, Moll and Stegwee 1978, Sabater and Rodriguez 1978, Shimokawa et al. 1978, Moll and De Witt 1979, Kuroki et al. 1981, Owens and Falkowski 1982, Amir-Shapira et al. 1986, Rodriguez et al. 1987, Za pat a et al. 1987). A particularly rich source of this enzyme is the diatom Phaeodactylum tricornutum (B a r ret and Jeffrey 1964, Terpstra 1978, 1980). Acetone extracts of this alga provide a crude but 
ready source of chlorophyllase (Terpstra and Goed heer 1979, La mbers et al. 1985). In vitro chlorophyllase catalyses esterification, transesterification and hydrolysis at the propionic side chain of chlorophyll (Shimizu and Ta maki 1963, Chiba et al. 1967, Wellburn 1970, Ellsworth 1971, 1972a, b, Ichinose and Sasa 1973, Holden 1976). The enzyme affects only chlorophylls, including bacteriochlorophylls and the corresponding pheophytins (Bogorad 1966), and esterifies chlorofillides (Moll and De Witt 1979, Kuroki et al. 1981, Michalski et al. 1987). Chlorophyllase has been generally regarded as a membrane-bound enzyme intimately associated with stroma lamellae of chloroplasts (Terpstra 1976, Terpstra and Goedheer 1975, 1979, Moll and De Witt 1979, Owens and Falkowski 1982, Terpstra and Lambers 1983, Lambers et al. 1985, Schuch and Brown 1987). In contrast to the membrane-bound enzyme, Ogura $(1969,1972)$ was the first who demonstrated the presence of a soluble chlorophyllase in young tea leaf sprouts.

The apparent molecular weight of the enzyme purified from different plants was determined in the range of $110-350 \mathrm{kDa}$ (Terpstra 1978, Kuroki et al. 1981, Shimokawa 1982, Lambers et al. 1985). It is suggested to be, at least in the case of Phaeodactylum tricornutum, a glycoprotein composed of several subunits of about $38 \mathrm{kDa}$ each. This aggregation characteristic has been reported for chlorophyllases from sugar beet (Bacon and Holden 1970), wheat (Ellsworth 1971), Phaseolus vulgaris (Moll and Stegwee 1978), Phaeodactylum tricornutum (Terpstra 1978, 1981), Chlorella (T a mai et al. 1979), tea leaf sprouts (Kuroki et al. 1981) and Citrus unshiu fruits (Shimokawa 1982). The possibility of the existence of two isozymes, each forming a high molecular aggregate, has also been considered ( $\mathrm{K}$ uroki et al. 1981, Tarasenko and Khodasevich 1987).

Purified chlorophyllases are roughly classified by their optimum $\mathrm{pH}$ into two groups. The first group consists of chlorophyllases with an acidic optimum such as those from Ailanthus altissima ( $\mathrm{pH} 4.5$; McFeeters et al. 1971) or tea leaf sprouts (pH 5.5-5.8; Ogura 1972, Kuroki et al. 1981). Chlorophyllases with a neutral optimum belong to the second group. Such enzymes as those from Chlorella vulgaris (pH 7.2-7.3; Böger 1965, Ichinose and Sa sa 1973), Chlorella protothecoides $(\mathrm{pH}$ 6.0-8.5; T a mai et al. 1979), sugar beet $(\mathrm{pH} 7.1$; Bacon and Holden 1970), tobacco (pH 7.0-7.5; Shimizu and Tamaki 1963) or Citrus unshiu fruits ( $\mathrm{pH} 7.0$; Shimokawa 1982) are found here. Temperature dependence of chlorophyllase activity varies according to the source of the enzyme showing maximum activity in the range of $30-40^{\circ} \mathrm{C}$ (Ardao and Vennesland 1960, Chiba et al. 1967, McFeeters et al. 1971, Ichinose and Sasa 1973, Moll and Stegwee 1978, Terpstra 1978, Shioi et al. 1980, Kuroki et al. 1981) but an optimum of $20^{\circ} \mathrm{C}$ has also been reported for chlorophyllase isolated from Citrus unshiu fruits (Shimokawa 1982). 
CHLOROPHYLLASE AND CHLOROPHYLL METABOLISM - WISHFUL THINKING AND REALITY

Though chlorophyllase is so widely distributed in the plant world, its physiological function is still largely unknown (Holden 1976, Terpstra 1981, Owens and Falkowski 1982, Schoch and Brown 1987). Chlorophyll breakdown should be considered as falling into two types (Hend ry et al. 1987). The first type, called according to the nomenclature of Hendry et al. (1987), type I degradation, includes loss of magnesium, phytol and possible modifications of the side chains of the chlorophyll molecule to yield pheophytin and pheophorbide. The second - called type II degradation, involves cleavage of the macrocyclic ring system and its subsequent degradation to smaller fragments. If we assume that the function of chlorophyllase is degradative, then it is undoubtely implicated in type I reactions. However, because this enzyme, under certain in vitro conditions, catalyzes the formation of the phytol ester bond, its role in vivo was for many years widely believed to be rather biosynthetic. It was Willstätter and Stoll (1913) who first reported that chlorophyll was formed from chlorophyllide and phytol after incubation with the air-dried meal of Hordeum leaves for more than $24 \mathrm{~h}$. Although their direct followers (Holden 1961, Klein and Vishniac 1961) were unable to achieve this phytylation, experiments on the role of chlorophyllase in the phytylation of chlorophyllide were continued for nearly 20 years. In 1962-1963 Shimizu and Tamaki also claimed that their enzyme preparation from tobacco leaves esterifies both chlorophyllide and pheophorbide with phytol in vitro. Chiba et al. (1967) reported that a chlorophyllase preparation from $\mathrm{Chlorella}$ cells catalyzed in vitro formation of chlorophyll from methyl chlorophyllide and phytol. Also Hines and Ellsworth (1969) suggested the participation of methyl chlorophyllide, phytol and chlorophyllase in the final steps of chlorophyll $a$ biogenesis. More recently, Ganoza and McFeeters (1976) observed a parallel increase in chlorophyll and chlorophyllase activity during greening of Chlorella protothecoides. On the other hand, high levels of chlorophyllase activity were also found by these authors during bleaching of the algal culture. Their results seemed to confirm the hypothesis of Ichinose and S a s a (1973) that chlorophyllase, at least that of Chlorella protothecoides, consists of two enzymes. One enzyme would catalyze chlorophyll $a$ hydrolysis, whereas the other transphytylation of chlorophyllide $a$. A similar, but more precisely expressed suggestion, has also been put forward by Ellsworth et al. (1976). According to it, the "chlorophyllase" activities observed in vitro were most likely due to two enzymes:

1. a chlorophyll $a$ (or pheophytin $a$ ) hydrolytic enzyme - chlorophyllase (E.C. 3.1.1.14), and

2. a chlorophyllide $a$ phytylating enzyme (system or multienzyme complex?).

Finally, a year later R üdiger et al. (1977) first detected the enzymic activity, 
termed "chlorophyll synthetase". Chlorophyll synthetase was found in etioplasts (Rüdiger et al. 1980), in chloroplasts (Block et al. 1980, Soll and Schultz 1981, Soll et al. 1983), and in chlorophyll-free chromoplasts (Kreuz and Kleinig 1981). It is localized in prothylakoid fractions of oats and wheat etioplasts (Lütz et al. 1981, Lindsten et al. 1989), in the stromal fraction of chromoplasts (K reuz and Kleining 1981) and in the prolamellar bodies (Lindsten et al. 1989). It is probably a peripheral thylakoid membrane protein (Rüdiger and Benz 1984, Rüdiger 1987). Most of the properties of chlorophyll synthetase evidently differ from those of chlorophyllase (Table 1). Thus, it seems obvious now that we should concentrate our subsequent discussion on the degradative properties of chlorophyllase and its role in the catabolism of chlorophyll, i.e. participation in the so-called type I degradation mentioned at the beginning of this chapter.

Table 1

Chlorophyllase versus chlorophyll synthetase in the esterification of chlorophyllide (data based on Ellsworth 1971, 1972a, Rüdiger et al. 1980, Rüdiger and Benz 1984)

\begin{tabular}{|c|c|c|}
\hline Properties & $\begin{array}{l}\text { Chloro- } \\
\text { phyllase }\end{array}$ & $\begin{array}{l}\text { Chlorophyll } \\
\text { synthetase }\end{array}$ \\
\hline Activity in phosphate buffer & $\operatorname{tr}$ & + \\
\hline $\begin{array}{l}\text { Activity in the presence of detergents or organic } \\
\text { solvents }\end{array}$ & + & - \\
\hline Diphopsphate derivatives of isoprenoid alcohols & - & + \\
\hline Free isoprenoid alcohols without ATP & + & - \\
\hline Alcohols other than $\mathrm{C}_{20}$ isoprenoids & + & $\operatorname{tr}$ \\
\hline Pheophorbide, bacteriochlide & + & - \\
\hline Pchlide & - & - \\
\hline Chlide $a, b$ & + & + \\
\hline Yield & & \\
\hline (amount of esterified product) & $1-15 \%$ & ca. $90 \%$ \\
\hline
\end{tabular}

(+) - activity; (tr) - trace of activity; (-) - no activity

Let's then return to the hydrolytic properties of chlorophyllase. Numerous studies have been carried out on this subject, mainly on chlorophyllase from Phaeodactylum tricornutum mentioned in the previous chapter. Although the activity of this enzyme could not be detected in vivo in unbroken cells, it was easily measured after disruption of thylakoid membranes (Terpstra and Goedheer 1975, Terpstra 1976, Owens and Falkowski 1982, Terpstra and Lambers 1983). A wide range of substances may effect the activity of chlorophyllase, among them cations, thiol reagents, fatty acids, lipids and detergents. Divalent cations $\mathrm{Mg}^{2+}$ and $\mathrm{Ca}^{2+}$ appeared to be more effective in stimulation of chlorophyllase activity than monovalent ones; while anion valency was of little importance (Terpstra and Goedheer 1975, Terpstra 1975, 1977, 1978, Owens and Falkowski 1982). 
An inhibitor of sulfhydryl residues - p-mercurobenzoate (PCMB) was reported to have a more diverse effect. It inhibited the activity of chlorophyllases from Euglena gracilis and Skeletonema costatum (Terpstra 1977, Owens and Falkowski 1982), but was ineffective on the Phaeodactylum tricornutum enzyme (Terpstra 1977), which suggested the lack or masking of free sulfhydryl groups in the active site of this particular chlorophyllase. Oleic acid, at a concentration of 1-8 times that of chlorophyll, increased internal chlorophyll to chlorophyllide conversion in osmotically shocked Phaeodactylum cells (Terpstra and Goedheer 1975). Unsaturated fatty acids, including oleic acid, may be considered to act as detergents, especially when used at such high concentrations. Their positive effect on the activity of chlorophyllase should then be ascribed to the disintegration of the lamellar structure of chloroplasts with further decomposition of chlorophyll-protein complexes, thus allowing contact between the substrate and the enzyme. Ionic as well as nonionic synthetic detergents are very often used in in vitro studies on chlorophyllase. Low concentrations of detergents such as sodium deoxycholate, lauryl diamine oxide or Triton X-100 markedly enhanced the hydrolytic activity of the enzyme (Schoch and Brown 1987, Tarasenko and Khodasevich 1987), whereas sodium dodecyl sulfate showed the opposite effect (Tarasenko and Khodasevich 1987). A similar inhibitory effect was observed while using high concentrations of Triton X-100 (Terpstra 1980). This effect could possibly be ascribed to the formation of micelles blocking the access of the enzyme to the substrate. or even to denaturation of the enzymic protein (Tarasenko and Khodasevich 1987). There also exists the possibility of replacing a natural esterifying group like phytol with Triton $\mathrm{X}-100$ to produce tritonyl esters of chlorophyll competitive with the natural substrate (Michalski et al. 1987). The existence of at least major amounts of the whole cellular pool of chlorophyllase as more or less tightly bound to the thylakoid membranes inspired some researchers to investigate the effect of chloroplast acyl lipids on the activity of chlorophyllase. Most data on this subject came from Terpstra's laboratory (Terpstra 1980, Terpstra 1982, Terpstra and Lambers 1983, Lambers and Terpstra 1985).

Phosphatidylcholine (lecithin) showed some positive effect on chlorophyllase activity (Terpstra 1980), which was later interpreted as rather indirect. The enhancement of hydrolysis of chlorophyll incorporated in phosphatidylocholin liposomes was brought about by removal of chlorophyllidae due to the incorporation of this product into liposomes, thus preventing feedback inhibition (Terpstra 1982). Monogalactolipids and digalactolipids which are major lipid constituents of thylakoid membranes showed opposite effects on the activity of chlorophyllase. Monogalactolipid, stimulating the monomerization of chlorophyll, enhanced the enzymic activity, whilst digalactolipid caused crystallization of chlorophyll molecules and loss of contact between the enzyme and substrate (La m bers et al. 1984, La mbers and Terpstra 1985). 
A similar effect was also observed for sulfolipid and phosphatidylglycerol, both being strongly anionic chloroplast lipids (Terpstra and Lambers 1983). It was also shown that these anionic lipids may fuse with chlorophyllase and inactivate the enzyme. $\mathrm{Mg}^{2}{ }^{+}$ions, linking to the negatively charged head groups of these lipids, might cause dissociation of the lipids from the active site of the enzyme allowing it to function properly (Lambers and Terpstra 1985). Local changes in the concentrations of divalent cations such as $\mathbf{M g}^{2+}$ together with strong enzyme-anionic lipid interactions may be a kind of regulatory mechanism of the activity of intramembraneous chlorophyllase (Terpstra and Goedheer 1975, Lambers and Terpstra 1985). It should be noted here that, although many attempts have been made to explain the mechanism of activation of chlorophyllase in vivo, the problem itself still awaits clarification.

Another intriguing and important problem is the way in which chlorophyllase binds chlorophyll to its active site. Obtaining definitive experimental data for this enzyme has been hindered because both the enzyme and its substrate are insoluble in aqueous buffers. Many procedures have been developed to solubilize chlorophyllase from a number of plant tissues and the solubilization of both the enzyme and its substrate has usually been accomplished by using buffers containing high concentrations of acetone or methanol, and/or low concentrations of detergents like Triton X-100. It is difficult to interpret the reaction kinetics of the enzyme under such different conditions. Moreover, the substrate is only partially soluble even at high $-45-66 \%$ concentrations of acetone (Ardao and Vennesland 1960, Bacon and Holden 1970). Nevertheless, some conclusions have been drawn. Seiler and Grob (1969) proposed that the substrate is held in the active site of chlorophyllase by hydrogen bonding of the 7 and 8 hydrogens to the sulfur atoms of a disulfide bond, and by the coordination bond between the keto group at C-9 and a metal ion in the enzyme. Since Fleming (1967) and Brockmann (1968) established the absolute configuration of chlorophyll which places the 7 and 8 hydrogens on the opposite side of the plane of the porphyrin ring and because sulfur atoms are not likely to form hydrogen bonds, this type of bonding seemed to be rather impossible. More recent data, however, point out that ring $\mathrm{V}$ of the chlorophyll molecule with its keto group at C-9 is essential for substrate-enzyme binding. Compounds without ring V or, for some reasons, lacking keto group in this ring, do not bind well to the enzyme (McFeeters 1975, Michalski et al. 1987).

\section{TO BE OR NOT TO BE INVOLVED IN CHLOROPHYLL CATABOLISM?}

"... according to present ignorance, the chlorophyll simply disappears" Matile et al. (1988). This sentence fits perfectly the beginning as well as the end of any review article considering the biochemical mechanism of chloro- 
phyll degradation. Our present knowledge about this phenomenon consists mostly of question marks, and incomplete and random biochemical reactions leading to nowhere. The intermediates of the chlorophyll breakdown in vivo are normally not accumulated and, therefore, almost undetected. The final products of degradation are not known, nor has the mechanism of $\mathrm{Mg}$-porphiryn catabolism been elucidated. The fate of the four nitrogen atoms of the chlorophyll molecule also remains unknown. The gap of knowledge is also largely due to the fact that intermediary non-green products of chlorophyll breakdown have yet not been indentified well. So far mainly derivatives having an intact porphyrin ring have been claimed to be the possible first natural products of chlorophyll $a$ degradation in vivo. This is surprising in view of the well-known breakdown of other porphyrins such as, for instance, hemoglobin. The elucidation of chlorophyll catabolism is a challenge because the current data about yellowing of leaves and color changes of fruits suggest that it is an orderly process (Goldschmidt 1980). In the functional state, the chlorophylls are associated with the apoproteins of light-harvesting and reaction center complexes of photosystems. Thus, it must be assumed that disassembly of thylakoids and dissociation of protein-pigment complexes must precede or initiate the first steps of chlorophyll catabolism. It still remains unknown whether dephytylation by the action of chlorophyllase is the first step of this process necessary for further breakdown.

Several recent reports indicate that the removal of the phytol chain by chlorophyllase might be one of the initial steps of the natural breakdown of chlorophyll during senescence (Sabater and Rodriguez 1978, Purvis and Barmore 1981, Owens and Falkowski 1982, Hirschfeld and Goldschmidt 1983, Ziegler et al. 1988). Chlorophyllase appears to be a component of the thylakoid membranes but it does not normally interact with its substrate situated in the same membrane (Terpstra and Weijman 1972, Terpstra and Goedheer 1975, Terpstra 1975, 1976, 1977, 1978, 1980, Hirschfeld and Goldschmidt 1983, Schoch and Brown 1987). A kind of structural separation should then exist which does not permit the hydrolysis of chlorophyll by the enzyme. Disruption of the thylakoid membrane during senescence should bring the enzyme and substrate into contact and start the degradation of the pigment. However, doubts regarding the physiological significance of chlorophyllase in the natural breakdown of chlorophyll still prevail. Chlorophyllase is present in green plant tissue before the onset of senescence and the problem of how the destruction of chlorophyll is really triggered is far from clear (Phillips et al. 1969, Thomas and Stoddart 1975). Detergents and other membrane-disrupting treatments did set the hydrolysis of chlorophyll into motion in chloroplast fragments (A mir-Shapira et al. 1986). It is, however, not clear whether in vivo the increase in chlorophyllase activity arises by de novo synthesis of the enzyme protein or by some other forms of activation. 
Recently, A mir-Shapira et al. (1987) demonstrated the in vivo accumulation of large amounts of chlorophyllide $a$ in senescing Citrus reticulata peel and the accumulation of pheophytin $a$ and other phytylated derivatives in dark-senescing parsley leaves. The results of these experiments suggest that different initial steps of the degradative pathways for chlorophyll might exist, as has been frequently reported (Shimizu et al. 1966, Mukherji and Biswas 1981, Schoch et al. 1981, Owens and Falkowski 1982, Maunders et al. 1983, Schoch and Vielwerth 1983, Amir-Shapira et al. 1986, Ziegler et al. 1988, Thomas et al. 1989). Thus, the possible existence of "tangerine-like" (accumulation of chlorophyllide- and pheophorbide-like materials) and "parsley-like" (phytylated derivatives) initial routes of chlorophyll catabolism in vivo should be considered.

Matile et al. (1988) have recently reported that although a small but significant proportion of pink pigments with the chemical properties of chlorophyll catabolites were recovered from the plastid fraction in senescing barley leaves, the bulk of these compounds can be assigned to the vacuole. The catabolites were already dephytylated, which indicates the importance of the removal of the phytol side chain for the first steps of chlorophyll breakdown. Another very important aspect of this finding is that we should look for the later steps of the chlorophyl degradation pathway outside rather than inside the chloroplasts.

We started our considerations from the point where the loss of chlorophyll in the photosynthetic tissues is inevitable and can be easily recognized - from senescence of plants in general and that of photosynthetic apparatus in particular. However, we should remember that the turnover of chlorophylls also occurs in healthy tissues during their whole lifetime. This turnover is well documented and the process has been monitored in photosynthetic bacteria (Haidl et al. 1985), in algae (Grombach et al. 1978, Riper et al. 1979) and in higher plants (Perkins and Roberts 1963, Stobart and Hendry 1984, Gaponenko et al. 1986, Hendry and Stobart 1986). The recent precise data on the constants and half-lives for turnover indicate that the destruction of chlorophyll occurs not only in the premature and senescent steps but throughout the entire plant life. The observed rates of chlorophyll turnover, i.e. half-lives of several hours to few days imply that a significant amount of chlorophyll is destroyed during the pre-senescent stage of growth (Grombach et al. 1978, Riper et al. 1979, Stobart and Hendry 1984, Hendry and Stobart 1986). And again, the extent to which chlorophyllase participates in this phenomenon remains obscure. On nearing the conclusion of this review we have found ourselves back at the starting point of this chapter where the question was put about the participation of this specific enzyme in the catabolism of chlorophyll in vivo. Chlorophyllase is the only well-defined enzyme system that has so far been shown to be involved in one way or another in the degradation of chlorophyll. Since other enzyme systems 
of this process await characterization or are still to be discovered, only a complete elucidation of the initial reactions occurring within the chloroplasts and yielding the first breakdown products of Mg-porphiryns will answer this question.

\section{Acknowledgements}

This work was supported by the project CPBP 05.02.1.10 of the Polish Academy of Sciences. The wonderful and stimulating atmosphere of the Department of Plant Physiology (University of Umeå, Sweden) headed by Professor Gunnar Öquist, where this review was largely written, is greatly acknowledged.

\section{REFERENCES}

Aiga I., Sasa T., 1970. Studies on chlorophyllase of Chlorella protothecoides. II. Formation of atypical chlorophyllide $a$. Plant Cell Physiol. 11: 161-165.

Amir-Shapira D., Goldschmidt E. E., Altman A., 1986. Autolysis of chlorophyll in aqueous and detergent suspensions of chloroplast fragments. Plant Sci. 42: 201-206.

Amir-Shapira D.; Goldschmidt E. E., Altman A., 1987. Chlorophyll catabolism in senescing tissues: In vivo breakdown intermediates suggest different degradative pathways for Citrus fruit and parsley leaves. Proc. Natl. Acad. Sci. USA 84: 1901-1905.

Ardao C., Vennesland B., 1960. Chlorophyllase activity of spinach chloroplastin. Plant Physiol. 35: 368-371.

Bacon M. F., Holden M., 1967. Changes in chlorophyll resulting from various chemical and physical treatments of leaves and leaf extracts. Phytochemistry 6: 193-210.

Bacon M. F., Holden M., 1970. Chlorophyllase of sugar-beet leaves. Phytochemistry 9: 115-125.

Barrett J., Jeffrey S. W., 1964. Chlorophyllase and formation of an atypical chlorophyllide in marine algae. Plant Physiol. 39: 44-47.

Björkmann O., 1981. Photosynthetic responses to different quantum flux densities. In: Encyclopedia of plant physiology - New Series. Lange O. L., Nobel P. S., Osmond S. D., Ziegler H. (eds.). Springer Verlag, Berlin, V. 12A, pp. 57-107.

Block M. A., Joyard J., Douce R., 1980. Site of synthesis of geranylgeraniol derivatives in intact spinach chloroplasts. Biochim. Biophys. Acta 631: 210-219.

Bog or a d L., 1966. The biosynthesis of chlorophylls. In: The chlorophylls. Vernon L. P., Seely G. R. (eds.). Academic Press, New York and London, pp. 481-510.

Böger P., 1965. Chlorophyllase of Chlorella vulgaris Beijerinck. Phytochemistry 4: 435-443.

Brockmann H., Jr., 1968. Zur absoluten Konfiguration des Chlorophylls. Angew. Chem. 80: 233-234.

Castelfranco P. A., Beale S. I., 1983. Chlorophyll biosynthesis: recent advances and areas of current interest. Annu. Rev. Plant Physiol. 34: 241-278.

Chiba Y., Aiga M., Idemori M., Satoh Y., Matsushita K., Sasa T., 1967. Studies on chlorophyllase of Chlorella protothecoides. I. Enzymatic phytylation of methyl chlorofillide. Plant Cell Physiol. 8: 633-635.

Ellsw orth R. K., 1971. Studies on chlorophyllase. I. Hydrolytic and esterification activities of chlorophyllase from wheat seedlings. Photosynthetica 5: 226-232.

Ellsworth R. K., 1972a. Studies on chlorophyllase. II. The effects of changes in reaction conditions on hydrolytic and esterification activities observed in preparations from wheat seedlings. Photosynthetica 6: 32-40. 
Ellsworth R. K., 1972b. Studies on chlorophyllase. III. Differences in gel chromatographic behavior of the hydrolytic and esterification activities obtained from wheat seedlings. Photosynthetica 6: 276-281.

Ellsworth R. K., Tsuk R. M., St. Pierre L. A., 1976. Studies on chlorophyllase. IV. Attribution of hydrolytic and esterifying "chlorophyllase" activities observed in vitro to two enzymes. Photosynthetica 10: 312-323.

Fleming I., 1967. Absolute configuration and structure of chlorophyll. Nature 216: 151-152. Ganoza V. G., McFeeters R. F., 1976. Chlorophyllase activity during pigmentation changes in Chlorella protothecoides. Photosynthetica 10: 1-6.

Gaponenko V. I., Nikolaeva G. N., Zherakova I. V., Doyna V. S., Trufanowa N. I., Kashevskaya O. V., Babich N. S., 1986. Chlorophyll turnover in the shoots of barley of different productivity. Plant Physiol. (Moscow) 33: 684-691.

Goldschmidt E. E., 1980. Pigment changes associated with fruit maturation and their control. In: Senescence in plants. Thimann K. V. (ed.). CRC Press Inc., Boca Raton, Florida, pp. 207-217.

Grombach K. H., Lichtenthaler H. K., Erismann K. H., 1978. Incorporation of ${ }^{14} \mathrm{CO}_{2}$ in photosynthetic pigments of Chlorella pyrenoidosa. Planta 140: 37-43.

Haidl H., Knodlmayer K., Rüdiger W., Scheer H., Schoch S., Ulrich J., 1985. Degradation of bacteriochlorophyll $a$ in Rhodopseudomonas sphaeroides R. 26. Z. Naturforsch. $40 \mathrm{c}: 685-692$.

Hendry G. A. F., St obart A. K., 1986. Chlorophyll turnover in greening barley. Phytochemistry $25: 2735-2738$.

Hendry G. A. F., Houghton J. D., Brown S. B., 1987. The degradation of chlorophyll a biological enigma. New Phytol. 107: 255-302.

Hines G. D., Ellsw orth R. K., 1969. Methyl chlorophyllide $a$ as a probable intermediate in the chlorophyll $a$ pathway. Plant Physiol. 44: 1742-1744.

Hirschfeld K. R., Goldschmidt E. E., 1983. Chlorophyllase activity in chlorophyll-free citrus chromoplasts. Plant Cell Rep. 2: 117-118.

Holden M., 1961. The breakdown of chlorophyll by chlorophyllase. Biochem. J. 78: 359-364.

Holden M., 1976. Chlorophylls. In: Chemistry and biochemistry of plant pigments. Goodwin T. W. (ed.). Academic Press, New York-London, V. 2, pp. 1-32.

Ichinose N., Sasa T., 1973. Studies on chlorophyllase of Chlorella protothecoides. III. Purification and catalytic properties. Plant Cell Physiol. 14: 1157-1166.

Jackson A. H., 1976. Structure, properties and distribution of chlorophylls. In: Chemistry and biochemistry of plant pigments. Goodwin T. W. (ed.). Academic Press, New York and London, V. 1, pp. 1-63.

Jones O. T. G., 1969 Chlorophylls and related pigments. In: Data for biochemical research. Dawson R. M. C., Elliot D. C., Elliot W. H., Jones K. M. (eds.). Clarendon Press, Oxford, pp. $318-320$.

Jones O. T. G., 1978. Biosynthesis of porphiryns, hemes and chlorophylls. In: The photosynthetic bacteria. Clayton R. K., Sistrom W. R. (eds.). Plenum Press, New York, pp. 751-777.

Jones O. T. G., 1979. Chlorophyll biosynthesis. In: The porphiryns. Dolphin D. (ed.). Academic Press, New York and London, V. 6, pp. 179-232.

Klein A. O., Vishniac W., 1961. Activity and partial purfication of chlorophyllase in aqueous systems. J. Biol. Chem. 236: 2544-2547.

Kreuz K., Kleinig H., 1981. Chlorophyll synthetase in chlorophyll-free chromoplasts. Plant Cell Rep. 1: 40-42.

Kuroki M., Shioi Y., Sasa T., 1981. Purification and properties of a soluble chlorophyllase from tea leaf sprouts. Plant Cell Physiol. 22: 717-725.

Lambers J. W. J., Verkleij A. J., Terpstra W., 1984. Reconstitution of chlorophyllase with mixed plant lipids in the presence and absence of $\mathrm{Mg}^{2+}$. Influence of single and mixed plant lipids on enzyme stability. Biochim. Biophys. Acta 786: 1-8. 
Lambers J. W. J., Terpstra W., 1985. Inactivation of chlorophyllase by negatively charged plant membrane lipids. Biochim. Biophys. Acta 831: 225-235.

Lambers J. W. J., Velthuis H. W., Terpstra W., 1985. Molecular mass estimation of chlorophyllase in situ by radiation inactivation analysis. Biochim. Biophys. Acta 831: 213-224.

Lindsten A., Ryberg M., Sundqvist C., 1989. Localization of chlorophyll synthetase activity in wheat etioplasts. In: Abstracts 8th Intern. Congress on Photosynthesis. Physiol. Plant. 76 (3, part 2): A137-754.

Lütz C., Benz J., Rüdiger W., 1981. Esterification of chlorophyllide in prolamellar body (PLB) and prothylakoid (PT) fractions from Avena sativa etioplasts. Z. Naturforsch. 36c: 58-61.

Matile P., Ginsburg P., Schellenberg M., Thomas H., 1988. Catabolites of chlorophyll in senescing barley leaves are localized in the vacuoles of mesophyll cells. Proc. Natl. Acad. Sci. USA 85: 9529-9532.

Munders M. J., Brown S. B., Woolhouse H. W., 1983. The appearance of chlorophyll derivatives in senescing tissue. Phytochemistry 22: 2443-2446.

McFeeters R. F., 1975. Substrate specificity of chlorophyllase. Plant Physiol. 55: 377-381.

MCFeeters R. F., Chichester C. O., Whitaker J. R., 1971. Purification and properties of chlorophyllase from Ailanthus altissima (Tree-of-Heaven). Plant Physiol. 47: 609-618.

Michalski T. J., Bradshaw C., Hunt J. E., Norris J. R., Katz J. J., 1987. Triton X-100 reacts with chlorophyll in the presence of chlorophyllase. FEBS Lett. 226: 72-76.

Moll W. A. W., Stegwee D., 1978. The activity of Triton X-100 soluble chlorophyllase in liposomes. Planta 140: 75-80.

Moll W. A. W., De Witt B., 1979. Chlorophyllase activity in plastid membranes of bean leaves grown in darkness and in (intermittent) light. Photosynthetica 13: 146-154.

Mukherji S., Biswas A. K., 1981. Penicilin action on chloroplast pigment composition, Hill reaction and chlorophyllase activity in Euphorbia pulcherrima L. leaf discs. Ind. J. Exp. Biol. 19: 70-72.

Ogura N., 1969. Studies on chlorophyllase of tea leaves. II. Seasonal change of a soluble chlorophyllase. Bot. Mag. Tokyo 82: 392-396.

Ogura N., 1972. Studies on chlorophyllase of tea leaves. III. Properties of soluble and insoluble chlorophyllases. Plant Cell Physiol. 13: 971-979.

Owens T. G., Falkowski P. G., 1982. Enzymatic degradation of chlorophyll $a$ by marine phytoplankton in vitro. Phytochemistry 21: 979-984.

Perkins H. J., Roberts D. W. A., 1963. On chlorophyll turnover in monocotyledons and dicotyledons. Can. J. Bot. 41: 221-226.

Phillips D. R., Horton R. F., Fletcher R. A., 1969. Ribonuclease and chlorophyllase activities in senescing leaves. Physiol. Plant. 22: 1050-1054.

Purvis A. C., Barmore C. R., 1981. Involvement of ethylene in chlorophyll degradation in peel of citrus fruits. Plant Physiol. 68: 854-856.

Riper D. M., Owens T. G., Falkowski P. G., 1979. Chlorophyll turnover in Skeletonema costatum, a marine phytoplankton diatom. Plant Physiol. 64: 49-54.

Rodriguez M. T., Gonzales M. P., Linares J. M., 1987. Degradation of chlorophyll and chlorophyllase activity in senescing barley leaves. J. Plant Physiol. 129: 369-374.

Rüdiger W., 1987. Chlorophyll synthetase and its implication for regulation of chlorophyll biosynthesis. In: Progress in photosynthesis research. Biggins J. (ed.). Martinus Nijhoff Publishers, Dordrecht, V. 4, pp. 461-467.

Rüdiger W., Hedden P., Kist H. P., Chapman D. J., 1977. Esterification of chlorophyllide by geranylgeranyl pyrophosphate in a cell free system from maize shoots. Biochim. Biophys. Res. Commun. 74: 1268-1272.

Rüdiger W., Benz J., Guth off C., 1980. Detection and partial characterization of activity of chlorophyll synthetase in etioplast membranes. Eur. J. Biochem. 109: 193-200. 
Rüdiger W., Benz J., 1984. Synthesis of chloroplast pigments. In: Chloroplast biogenesis. Ellis R. J. (ed.). Cambridge University Press, Cambridge, pp. 225-244.

Sabater B., Rodriguez M. T., 1978. Control of chlorophyll degradation in detached leaves of barley and oat through effect of kinetin on chlorophyllase levels. Physiol. Plant. 43: 274-276.

Schoch S., Scheer H., Schiff J. A., Rüdiger W., Siegelman H. W., 1981. Pyropheophytin $a$ accompanies pheophytin $a$ in darkened light-grown cells of Euglena. Z. Naturforsch. 36c: 827-833.

Schoch S., Vielwerth F. X., 1983. Chlorophyll degradation in senescent tobbacco cell culture (Nicotiana tabacum var. "Samsun"). Z. Pflanzenphysiol. 110: 309-317.

Schoch S., Brown J., 1987. The action of chlorophyllase on chlorophyll-protein complexes. J. Plant Physiol. 126: 483-494.

Seely G. R., 1966. The structure and chemistry of functional groups. In: The chlorophylls. Vernon L. P., Seely G. R. (eds.). Academic Press, New York and London, pp. 67-109.

Seiler J. P., Grob E. C., 1969. Substratspezifität und aktives Zentrum der Chlorophyllase. Chimia 23: 179-180.

Shimizu S., Tamaki E., 1962. Chlorophyllase of tobacco plants. I. Preparation and' some properties of water-soluble enzyme. Bot. Mag. Tokyo 75: 462-467.

Shimizu S., Tamaki E., 1963. Chlorophyllase of tobacco plants. II. Enzymic phytylation of chlorophyllide and pheophorbide in vitro. Arch. Biochem. Biophys. 102: 152-158.

Shimizu S., Hotta R., Tamaki E., 1966. Metabolism of chlorophyll in higher plants. III. Pheophytins, as one of the color components of some tobacco varieties. Bot. Mag. Tokyo 79: 560-565.

Shimokawa K., Schimada S., Yaeo K., 1978. Ethylene-enhanced chlorophyllase activity during degreening of Citrus unshiu Marc. Sci. Hortic. 8: 129-135.

Shimokawa K., 1982. Hydrophobic chromatographic purification of ethylene-enhanced chlorophyllase from Citrus unshiu fruits. Phytochemistry 21: 543-545.

Shioi Y., Tamai H., Sasa T., 1980. A simple purification method for the preparation of solubilized chlorophyllase from Chlorella protothecoides. Anal Biochem. 105: 74-79.

Soll J., Schultz G., 1981. Phytol synthesis from geranylgeraniol in spinach chloroplasts. Biochem. Biophys. Res. Commun. 99: 907-912.

Soll J., Schultz G., Rüdiger W., Benz J., 1983. Hydrogenation of geranylgeraniol. Two pathways exist in spinach chloroplasts. Plant Physiol. 71: 849-854.

Stobart A. K., Hendry G. A. F., 1984. The turnover of chlorophyll in greening wheat leaves. Phytochemistry 23: 27-30.

Strain H. H., Thomas M. R., Katz J. J., 1963. Spectral absorption properties of ordinary and fully deuterated chlorophylls $a$ and $b$. Biochim. Biophys. Acta 75: 306-311.

Svec W. A., 1978. The isolation, preparation, characterisation and estimation of the chlorophylls and the bacteriochlorophylls. In: The porphiryns. Dolphin D. (ed.). Academic Press, New York, V. 5, pp. 341-399.

Tamai H., Shioi Y., Sasa T., 1979. Studies on chlorophyllase of Chlorella protothecoides. IV. Some properties of the purified enzyme. Plant Cell Physiol. 20: 1141-1145.

Tarasenko L. G., Khodasevich E. V., 1987. Studies of chlorophyllase in chloroplast membranes. Plant Physiol. (Moscow) 34: 1090-1096.

Terpstra W., 1975. Chlorophyllase and lamellar structure in Phaeodactylum tricornutum. II. Conversion of added chlorophyll into chlorophyllide by small lamellar fragments. $\mathrm{Z}$. Pflanzenphysiol. 75: 405-414.

Terpstra W., 1976. Chlorophyllase and lamellar structure in Phaeodactylum tricornutum. III. Situation of chlorophyllase in pigmented membranes. Z. Pflanzenphysiol. 80: 177-178.

Terpstra W., 1977. A study of properties and activity of chlorophyllase in photosynthetic membranes. Z. Pflanzenphysiol. 85: 139-146. 
Terpstra W., 1978. Chlorophyllase in Phaeodactylum tricornutum photosynthetic membranes. Extractability, small scale purification and molecular weight determination by SDS-gel-electrophoresis. Physiol. Plant. 44: 329-334.

Terpstra W., 1980. Influence of lecithin liposomes of chlorophyllase-catalysed chlorophyll hydrolysis. Comparison of intramembraneous and solubilized Phaeodactylum chlorophyllase. Biochim. Biophys. Acta 600: 36-47.

Terpstra W., 1981. Identification of chlorophyllase as a glycoprotein. FEBS Lett. 126: 231-235. Terpstra W., 1982. Studies on chlorophyllase. The mechanism of the action of lecithin liposomes on enzyme activity and the function of the carbohydrate moiety of the enzyme. Biochim. Biophys. Acta 681: 233-241.

Terpstra W., Weijman A. C. M., 1972 Spinach protein factor and chlorophyllase. Planta 108: 319-331.

Terpstra W., Goedheer J. C., 1975. Chlorophyllase and lamellar structure in Phaeodactylum tricornutum. I. Chlorophyll-chlorophyllide conversion within the lamellae. Z. Pflanzenphysiol. 75: 118-130.

Terpstra W., Goedheer J. C., 1979. Chlorophyllase and photosystem 1. Methyloviologen photoreduction by DCPIP-ascorbate in the presence of photosynthetic membrane fragments, chlorophyll-Triton X-100 or chlorophyll-chlorophyllase. Physiol. Plant. 45: 367-372.

Terpstra W., La mbers J. W. J., 1983. Interaction between chlorophyllase, chlorophyll $a$, plant lipids and $\mathrm{Mg}^{2}$. Biochim. Biophys. Acta 746: 23-31.

Th om as H., Stoddart J. L., 1975. Separation of chlorophyll degradation from other senescence processes in leaves of a mutant genotype of meadow fescue (Festuca pratensis L.). Plant Physiol. 56: 438-441.

Thomas H., Bortlik K., Rentsch D., Schellenberg M., Matile P., 1989. Catabolism of chlorophyll in vivo: significance of polar chlorophyll catabolites in a non-yellowing senescence mutant of Festuca pratensis Huds. New Phytol. 111: 3-8.

Vernon L. P., 1960. Spectrophotometric determination of chlorophylls and phaeophytins in plant extracts. Anal. Chem. 32: 1144-1150.

Wellburn A. R., 1970. Studies on the esterification of chlorophyllides. Phytochemistry 9: 2311-2313.

Willstätter R., Stoll A., 1913. Untersuchungen über Chlorophyll. Methoden und Ergebnisse. Springer Verlag, Berlin, pp. 172-193.

Wintermans J. F. G. M., 1969. Comparative chlorophyll determinations by spectrophotometry of leaf extracts in different solvents. Photosynthetica 3: 112-119.

Zapata M., Ayala A. M., Franco J. M., Garrido J. L., 1987. Separation of chlorophylls and their degradation products in marine phytoplankton by reverse-phase high performance liquid chromatography. Chromatographia 23: 26-30.

Ziegler R., Schanderl S. H., 1969. Chlorophyll degradation and the kinetics of dephytylated derivatives in a mutant of Chlorella. Photosynthetica 3: 45-54.

Ziegler R., Blaheta A., Guha N., Schönegge B., 1988. Enzymatic formation of pheophorbide and pyropheophorbide during chlorophyll degradation in a mutant of Chlorella fusca Shihira et Kraus. J. Plant Physiol. 132: 327-332.

\section{Udzial chlorofilazy $w$ przemianach chlorofilu}

\section{Streszczenie}

Zjawisko degradacji chlorofili jest łatwe do zauważenia, jednakże los tych barwników fotosyntetycznych i ich katabolizm są dotychczas mało poznane. Enzym zwany "chlorofilazą" (hydrolaza chlorofil-chlorofilid, EC 3.1 .1 .14 ) przez wiele lat uważany był za enzym uczestniczący zarówno w biosyntezie, jak i w degradacji chlorofili. Obecnie wydaje się być faktem bezspornym, iż chlorofilaza in vivo uczestniczy w pierwszych etapach degradacji chlorofilu. 